\title{
PENGOLAHAN BERAS MERAH LOKAL PENEBEL (Oryza sativa Var. Barak Cendana) MENJADI TEH BERAS MERAH UNTUK MENINGKATKAN PENDAPATAN MASYARAKAT
}

\author{
N. N. Darmiati*1 dan N. M. S. Sukmawati ${ }^{2}$ \\ * Skim KKN PPM di Desa Babahan Kecamatan Penebel,Kabupaten Tabanan, Bali
}

\begin{abstract}
ABSTRAK
Kegiatan pengabdian kepada masyarakat ini bertujuan untuk memproduksi teh dari beras merah padi lokal Penebel (Oryza sativa Var. Barak Cendana) di Desa Babahan, Kecamatan Penebel, Kabupaten Tabanan, Bali.. Metode yang diterapkan dalam pemberdayaan masyarakat pada kegiatan Program KKN PPM (Kuliah Kerja Nyata Pembelajaran Pemberdayaan Masyarakt adalah: (1) Koordinasi dan komunikasi secara partisipasif dengan Kelompok wanita tani Desa Babahan untuk merumuskan program mulai dari perencanaan, operasional dan evaluasi; (2) Penyuluhan untuk membangun persepsi dan pemahaman Kelompok wanita Tani mengenai inovasi program yang diterapkan; (3) Bimbingan dan Pelatihan mengenai terapan ipteks yang diaplikasikan bagi Kelompok wanita Tani; (4) Pendampingan yaitu pertemuan secara berkala dan berkelanjutan antara pendamping dengan Kelompok wanita Tani Desa Babahan sehingga ipteks yang diaplikasikan dapat dilaksanakan secara tepat. Hasil pengabdian menunjukkan bahwa kelompok wanita tani Desa Babahan telah berhasil meningkatkan pengetahuannya dan meningkatkan keterampilannya sehinga bisa meningkatkan nilai tambah dari beras merah tersebut.
\end{abstract}

Kata kunci : beras merah, teh beras merah, peningkatan pendapatan

\begin{abstract}
The community service activity aims to produce tea from Penebel's local brown rice (Oryza sativa Var. Barak Cendana) in Babahan Village, Penebel District, Tabanan Regency, Bali. The method applied in community empowerment in KKN PPM (Work Lecture) Program activities Real Community Empowerment Learning is: (1) Participatory coordination and communication with women farmer groups or Female farmer groups joined in Babahan Village to formulate programs ranging from planning, operations and evaluation; (2) Counseling to build group perceptions and understanding (3) Guidance and Training on applied science and technology applied to Female farmer groups; (4) Mentoring is regular and ongoing meetings between assistants and the Babahan Village Farmer Women's Group so that the applied science and technology can be implemented appropriately. The results of dedication showed that the women farmer group in Babahan Village had succeeded in increasing their knowledge and improving their skills so that they could increase the added value of the brown rice.
\end{abstract}

Keywords : brown rice, brown rice tea, increased income

\section{PENDAHULUAN}

Subak di Desa Babahan dikenal sebagai sentra produsen utama beras merah (Oryza sativa var. Barak Cendana), bahkan produknya telah menembus ke pasar internasional, tetapi padi lokal Bali di desa Babahan belum diusahakan secara optimal sehingga belum mampu memberikan pendapatan yang signifikan bagi masyarakat, Disamping itu juga belum berkembangnya usaha

\footnotetext{
${ }^{1}$ Staf Pengajar Fakultas Petrtanian Universitas Udayana, nengahdarmiati@gmail.com

${ }^{2}$ Staf Pengajar Fakultas Peternakan Universitas Udayana
} 
rumahan yang mengolah hasil pertanian padi lokal menjadi produk olahan yang memberikan nilai tambah bagi kelompok wanita tani.

Sebagaimana telah diketahui bersama bahwa beras merah selain dijadikan sebagai bahan utama makanan, beras merah ternyata juga bisa dikonsumsi sebagai minuman sehat (teh) (Hasnil, 2017). Menurut Harjana (2016) beras merah mengandung berbagai nilai gizi untuk kesehatan seperti : Mangan , berfungsi untuk membantu produksi energi dari protein dan karbohidrat, serta membantu pembuatan asam lemak yang penting bagi sistem saraf. Magnesium, berfungsi untuk menguatkan tulang, juga menjadi bagian dari 300 enzim di dalam tubuh, termasuk enzim yang mengatur penggunaan insulin, yang berperan dalam penyakit diabetes. Serat, berfungsi mempercepat masa tinggal sisa makanan dalam usus, sehingga menurunkan risiko kanker usus. Beras merah juga kaya selenium, yang dapat mengurangi risiko kanker, meningkatkan metabolisme dan membuat kenyang untuk waktu yang lama. Karena konsentrasinya berserat, beras merah memberi efek yang membuat usus bergerak secara sehat dan dapat membantu menurunkan berat badan. Disamping kandungan zat tersebut, Frei (2004) juga menambahkan bahwa beras merah sangat bermanfaat bagi kesehatan karena mengandung karbohidrat, protein, betakaroten, antioksidan dan zat besi

Terdapat beberapa daerah di Indonesia yang telah menjadikan beras merah sebagai minuman seperti teh. Salah satu desa yang menjadi mitra dalam program KKN PPM yakni Desa Babahan, Kecamatan Penebel, Kabupaten Tabanan, Bali. Desa Babahan sebagai produsen utama beras merah, tetapi belum mampu memberikan pendapatan yang signifikan kepada warganya, disolusikan dengan memberikan pelatihan pengolahan beras merah lokal Penebel sebagai minuman sehat yakni teh beras merah. Dengan dijadikannya desa Babahan sebagai mitra KKN PPM, maka pengolahan beras merah menjadi teh beras merah merupakan salah satu bagian dari program pokok tema bidang peningkatan produksi. Pada kegiatan ini kelompok wanita tani desa Babahan diberdayakan dalam pelatihan pengolahan beras merah menjadi teh dengan mendatangkan narasumber. Kegiatan awal adalah pelatihan pengolahan yakni mengolah beras merah menjadi teh beras merah dengan rasa khas beras merah, tetapi kemudian dicobakan pengolahannya dengan menambah berbagai varian rasa, seperti rasa pandan wangi, rasa jahe, rasa jeruk nipis dan campuran rasa ketiganya.

Dengan cara seperti itu diharapkan kelompok wanita tani memiliki keterampilan baru yang dapat menjadi modal untuk membuka usaha sendiri. Selain mendapatkan pengetahuan tentang cara pengolahan, kelompok wanita tani juga diberikan penyuluhan tentang nilai gizi dan manfaat beras merah untuk kesehatan, serta mendapatkan ilmu tentang pemasaran yang baik dan benar sehingga nanti mampu bersaing dalam menjual teh beras merah

Berdasarkan uraian tersebut di atas, pengabdian kepada masyarakat ini bertujuan untuk mendampingi kelompok wanita tani di desa Babahan, Kecamatan Penebel, Kabupaten Tabanan Bali dalam pengolahan beras merah menjadi teh beras merah dengan berbagai varian rasa sehingga bisa meningkatkan nilai tambah dari beras merah tersebut, dan mampu meningkatkan pendapatan masyarakat.

\section{METODE PELAKSANAAN}

\subsection{Metode}

Metode yang diterapkan dalam pemberdayaan masyarakat pada kegiatan KKN PPM ini adalah sebagai berikut: (1) Penyuluhan untuk membangun persepsi dan pemahaman masyarakat khususnya Kelompok wanita tani desa Babahan mengenai inovasi atau program pembuatan teh dari beras merah yang diterapkan, (2) Pelatihan mengenai terapan ipeks pembuatan teh beras merah yang diaplikasikan bagi anggota Kelompok wanita tani dan (3) Pendampingan yaitu pertemuan 
secara berkala dan berkelanjutan antara pendamping dengan anggota Kelompok wanita tani hingga ipteks pembuatan teh yang diaplikasikan dapat dilaksanakan secara tepat

\subsection{Tahap Kegiatan}

Pelaksanan kegiatan alih teknologi dalam pengolahan beras merah menjadi teh beras merah sebagai berikut:

(1) Kordinasi dan komunikasi secara partisipasif dengan anggota Kelompok wanita tani untuk merumuskan program mulai dari perencanaan, operasional dan evaluasi.

(2) Penyuluhan tentang pentingnya pengolahan beras merah menjadi teh beras merah

(3) Pelatihan pengolahan beras merah menjadi teh beras merah.

(4) Proses pengolahan beras merah mrenjadi teh beras merah adalah sebagai berikut:

a) Menyiapkan alat seperti kompor, baskom besar, gelas, gunting atau pisau, wajan, panci besar, alat penyaring, sendok, alat timbangan dan kemasan

b) Menyiapkan bahan seperti beras merah, daun pandan wangi, jahe, buah jeruk nipis, dan air.

c) Bahan (daun pandan wangi, jeruk nipis dan jahe) dipotong - potong kemudian daun pandan wangi dan jahe diblender, tambahkan 1 gelas air matang, jeruk nipis diperas lalu campurkan dengan kedua bahan di atas lalu disaring. Beras merah yang sudah bersih, disangrai sampai setengah matang, kemudian diturunkan dari kompor. Beras dalam keadaan masih panas dicampur dengan perasan daun pandan wangi, jahe dan jeruk nipis selanjutnya ditunggu sampai dingin. Selanjutnya beras yang sudah bercampur dengan air perasan tadi, disangrai lagi sampai matang, kemudian didinginkan dalam suhu kamar. Teh beras merah tadi sudah siap dikemas.

\section{HASIL DAN PEMBAHASAN}

Hasil pendampingan pengolahan beras merah menjadi teh beras merah lokal Penebel (Oryza sativa Var. Barak Cendana) di Desa Babahan Kecamatan Penebel, Kabupaten Tabanan Bali menunjukkan bahwa untuk memproduksi $1 \mathrm{~kg}$ beras merah lokal Penebel menjadi teh dibutuhkan 150 gr jahe bali, 150 gr daun pandan wangi, dan 2 bh jeruk nipis.

Analisis ekonomi yang sangat sederhana berdasarkan harga -harga bahan saat ini dan hasil wawancara dengan salah satu warga di Dusun Dadia Desa Babahan yang sudah pernah membuat teh berbahan dasar dari beras merah menyatakan bahwa untuk memproduksi $1 \mathrm{~kg}$ teh dari beras merah, setelah mengalami proses sangrai akan didapatkan $900 \mathrm{~g}$ teh, jika dihargakan masingmasing bahan tersebut di atas maka untuk $1 \mathrm{~kg}$ beras harganya $=\mathrm{Rp} .25 .000 ; 150 \mathrm{~g}$ jahe bali harganya Rp. 2.000; 150 g daun pandan wangi harganya Rp. 2.000; 2 buah jeruk nipis harganya Rp. 3.000; 1 kemasan plastik harganya Rp. 2.500. Biaya untuk kompor Rp. 5.000; biaya tenaga kerja Rp. 10.000; Dari $900 \mathrm{~g}$ teh beras merah setelah dikemas menjadi 6 kemasan dengan berat masing-masing kemasan $150 \mathrm{~g}$, memerlukan plastik kemasan seharga Rp. 15.000; Jadi total biaya untuk membuat $1 \mathrm{~kg}$ teh beras merah adalah sebesar Rp. 62.000. Jika dijual per $150 \mathrm{gr}$ dengan harga Rp. 17.500; maka total penjualan adalah Rp. 105.000; jadi didapatkan keuntungan sebesar Rp. 43.000 per $1 \mathrm{~kg}$ beras merah. Jika hanya menjual beras merah saja tanpa diolah menjadi teh beras merah, harga beras merah Rp. 25.000; tetapi setelah diolah menjadi teh, ada peningkatan harga sebesar Rp. 18.000; per $1 \mathrm{~kg}$ nya. Dengan demikian produk olahan teh beras merah sangat menjanjikan, karena bisa meningkatkan nilai tambah dari beras merah, dengan demikian bisa meningkatkan pendapatan masyarakat. Selain bisa meningkatkan pendapatan masyarakat, teh beras merah masih memiliki kulit ari (bekatul) sehingga masih mengandung serat yang tinggi untuk mencegah penyakit saluran pencernaan, disamping itu juga beras merah yang sudah disangrai per 
100 gram nya memiliki komposisi kimia , senyawa bioaktif dan antioksidan seperti tertera dalam Tabel 3.1

Tabel 3.1 Komposisi kimia, senyawa bioaktif dan antioksidan dari $100 \mathrm{~g}$ teh beras merah sangrai

\begin{tabular}{|c|c|c|}
\hline No. & Komposisi & Teh beras sangrai \\
\hline 1. & Air $(\mathrm{g})$ & $4,00 \pm 0,06$ \\
\hline 2. & Abu $(\mathrm{g})$ & $0,02 \pm 0,006$ \\
\hline 3. & Protein $(\mathrm{g})$ & $8,14 \pm 0,06$ \\
\hline 4. & Karbohidrat $(\mathrm{g})$ & $79,94 \pm 0,03$ \\
\hline 5. & Lemak $(\mathrm{g})$ & $2,53 \pm 0,04$ \\
\hline 6. & Antosianin $(\mathrm{mg} / 100 \mathrm{~g})$ & $0,12 \pm 0,04$ \\
\hline 7. & Tannin $(\%)$ & $0,67 \pm 0,05$ \\
\hline 8. & anti oksidan $(\%)$ & $14,59 \pm 0,17$ \\
\hline
\end{tabular}

Sumber : Budisanjaya dkk., 2015

Bahan - bahan untuk menambah varian rasa teh beras merah seperti daun pandan wangi mengandung unsur gizi seperti : Tanin, alkaloid, flavonoid, dan polifenol yang berfungsi untuk mencegah penyakit kencing manis. Alkaloid, flavonoid, saponin, tanin, polifenol sebagai antioksidan dan senyawa terpenoid sebagai antikanker. (Yuwono, 2015). Jahe mengandung unsur gizi Gingerol dan shogaol sebagai antiinflamasi, antioxidant, menurunkan kolesterol darah dan mengatur gula darah serta sebagai antiinflamasi yang berfungsi sebagai penurun rasa nyeri/sakit pada penyakit rematik dan osteoarthritis (Wijaya, 2012), sementara jeruk nipis mengandung vitamin c, yang dapat membantu penyembuhan luka, dan baik untuk kesehatan mata (Sulaiman, 2017)

Oleh karena itu pembuatan teh berbahan dasar beras merah ditambah dengan varian rasa seperti daun pandan wangi, jahe dan jeruk nipis merupakan solusi yang baik untuk meningkatkan nilai tambah dari beras merah, sekaligus menambah unsur gizi yang terkandung dalam teh beras merah tersebut, yang mampu mencegah berbagai penyakit.

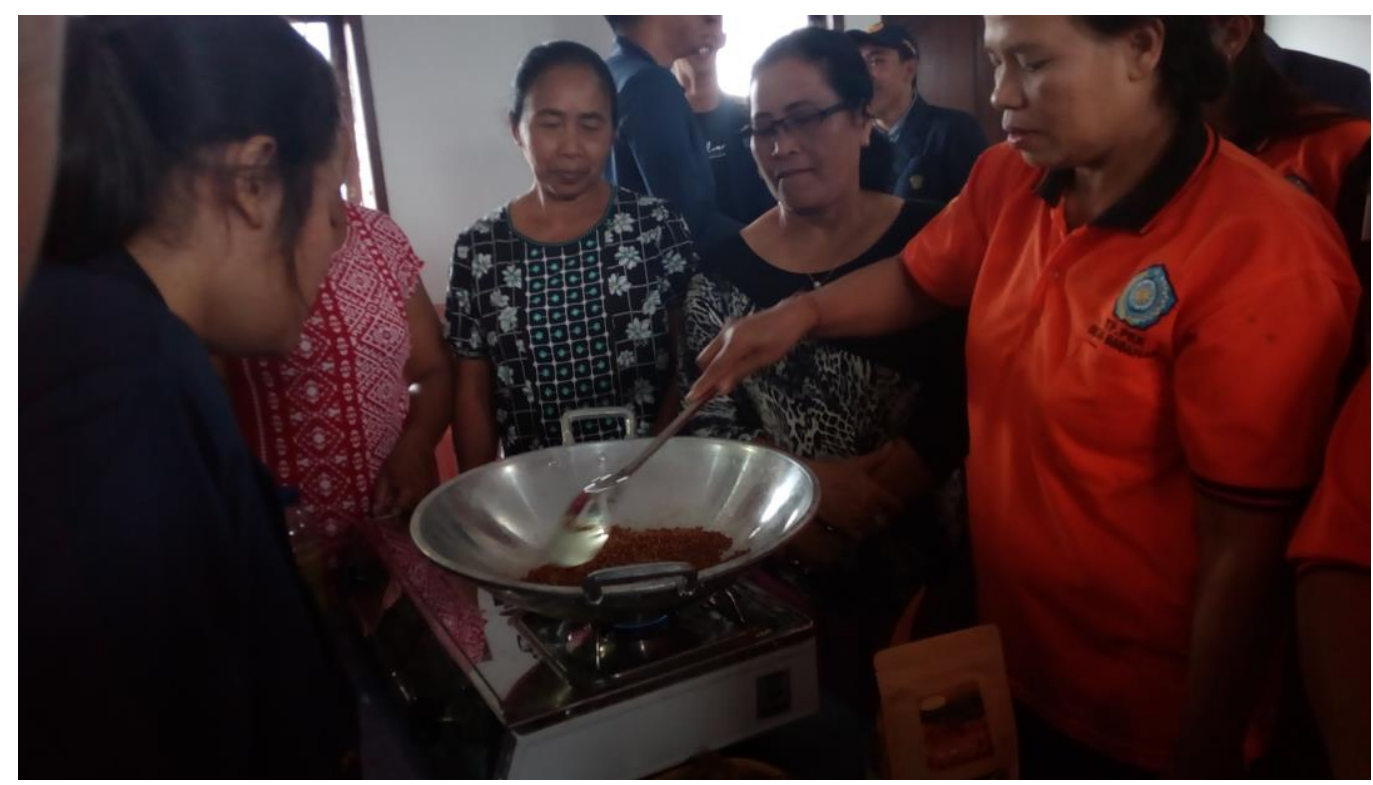

Gambar 3.1 Pengolahan beras merah menjadi teh 


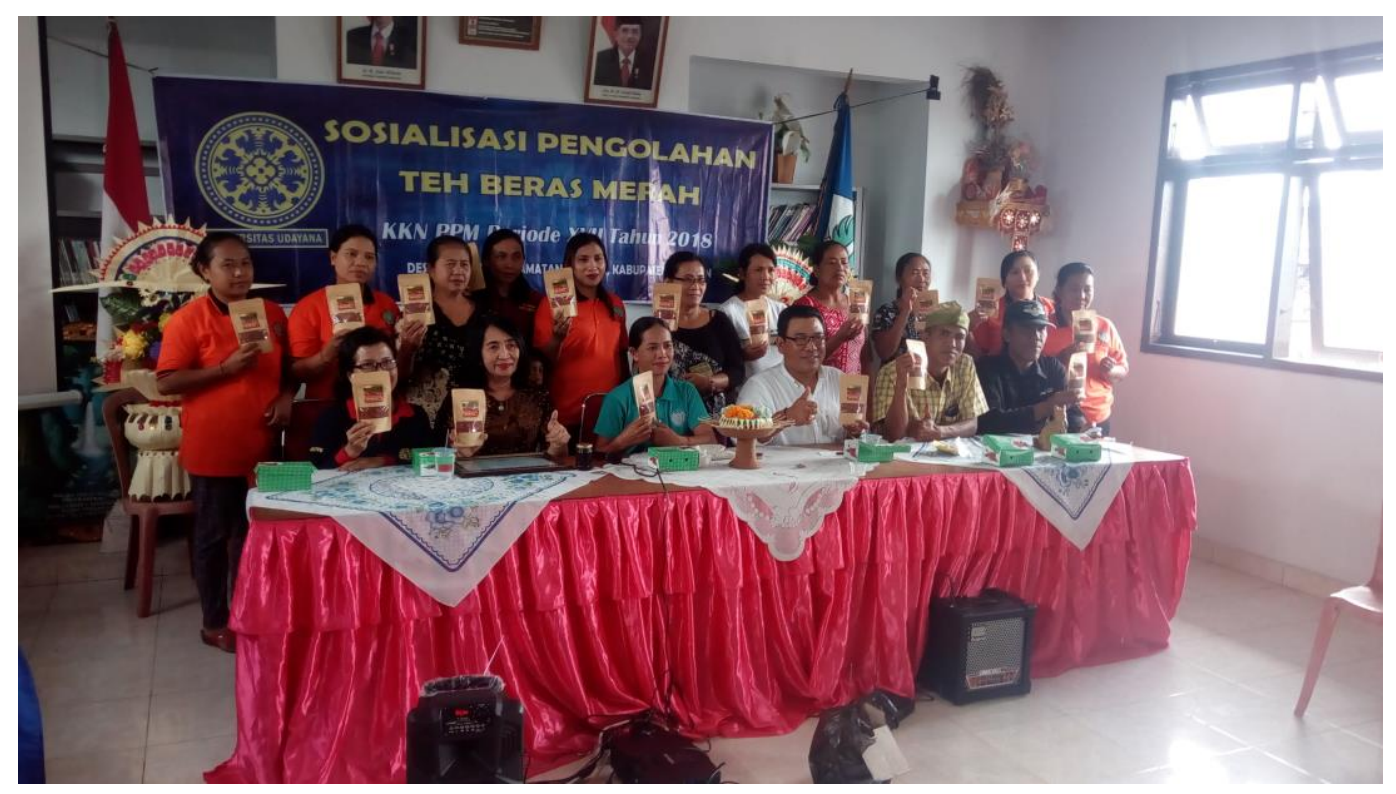

Gambar 3.2 Hasil pengolahan teh beras merah yang sudah dikemas

\section{KESIMPULAN DAN SARAN}

\subsection{Kesimpulan}

Produksi teh berbahan dasar dari beras merah lokal Penebel (Oryza sativa Var. Barak Cendana) dengan berbagai varian rasa cukup menjanjikan karena dapat meningkatkan nilai tambah dari beras merah tersebut sehingga mampu meningkatkan pendapatan masyarakat ( kelompok wanita tani) di Desa Babahan.

\subsection{Saran}

Kegiatan pengabdian kepada masyarakat ini sangat dibutuhkan oleh kelompok wanita tani Subak Babahan, maka sebaiknya dilaksanakan secara berkelanjutan.

\section{UCAPAN TERIMAKASIH}

Terima kasih kami sampaikan kepada Direktorat Jendral Penguatan Riset dan Pengembangan, Kementrian Riset, Teknologi dan Pendidikan Tinggi atas bantuan dana sehingga kegiatan KKN PPM di Desa Babahan dapat terlaksana dengan baik.

\section{DAFTAR PUSTAKA}

Budisanjaya, I.P.G. ; L.P. Wrasiati dan I.M.A.S. Wijaya, 2015. Pengaruh Metode Pemanasan Terhadap Karakteristik Mutu Beras Merah Jatiluwih. Media Ilmiah Teknologi Pangan, Vol. 2 No. 2, 115 - 121, 2015. ISSN : $2407-3814$.

Frei, K.B. 2004. Improving the Nutrient Availability in Rice Biotechnology or Biodiversity. In A. Wileke $(E d)$. Agriculture Development Contributing to International Cooperation 11(2) : 64 -65. 
Harjana, D. 2016. Kandungan Nutrisi Beras Merah dan Manfaatnya. Info Kesehatan. Diakses tanggal 8 Nopember 2018. https://manfaatnya sehat.blogspot.com/2014/05/kandungan -nutrisi-beras-merah

Hasnil, 2017. Membuat Minuman Sehat Dari Beras Merah. Diakses tanggal 8 Nopember 2018.

Ekafarm.id/resep-minuman-beras-merah.

Sulaiman, 2017. Jeruk Nipis , Kandungan dan Khasiatnya Bagi Kesehatan. Diakses tanggal 8 Nopember 2018. nusantaranews.co/jeruk-nipis-kandungan-dan -kasiatnya-bagi-kesehatan.

Wijaya, A. 2012. Kandungan dan Manfaat Jahe Bagi Kesehatan. Diaksews tanggal 8 Nopember 2018. permathic.blogspot.com/2012/05/kandungan-jahe-dan-manfaat jahe-bagi - kesehatan

Yuwono, S.S. 2015. Daun Pandan Wangi. Diakses tanggal 8 Nopember 2018.darsatop.lecture ub ac $\mathrm{id} / 2015 / 09 /$ daun-pandan-wangi-pandanus-amarylifolius. 